\title{
Assessment of Infrastructure Assets Induced by Water Level Fluctuation along the Bengawan Solo River
}

\author{
T.R. Satrya ${ }^{1, a)}$, R.A.A. Soemitro ${ }^{1, b)}$, M.A. Maulana ${ }^{1, c)}$, D.D. Warnana ${ }^{2, \mathrm{~d})}$ \& R. Soetanto ${ }^{3, \mathrm{e})}$ \\ 1) Civil Engineering Department, Institut Teknologi Sepuluh Nopember (ITS), Surabaya, Indonesia. \\ 2) Geophysics Engineering Dept., Institut Teknologi Sepuluh Nopember (ITS), Surabaya, Indonesia. \\ 3) School of Architecture, Building and Civil Engineering, Loughborough University, Loughborough, \\ United Kingdom.
}

Correspondent : $\left.{ }^{a}\right)$ rendy_star@ce.its.ac.id, $\left.{ }^{b}\right)$ ria@ce.its.ac.id, ${ }^{c}$ mahendrasipil@gmail.com \&

d)R.Soetanto@lboro.ac.uk

\begin{abstract}
The stability of infrastructure along river channel, such as bridges and embankments, is paramount to continuing service and public safety, and therefore, is essential consideration in the design, construction and maintenance. During the design process, infrastructure stability is often assumed to be static, and considered by implementing a safety factor which is produced by an analysis of extreme condition. However, this has failed to consider the variability of natural factors and importantly, the escalating threat of extreme environmental condition, induced by global climate change. This assumption should, therefore, be revisited for developing a more resilient design and maintenance regime. To demonstrate the changing infrastructure stability, an assessment of safety factor of river embankment and bridge foundation as nearby infrastructures along Bengawan Solo River's channel and estuary is presented. This was undertaken to determine the impact of water level fluctuation during two extreme conditions during dry and rainy seasons in several critical locations. The river characteristics (i.e. morphology, water fluctuations, velocity, and sub-soil characteristics), embankment conditions and bridge pile foundation were investigated in-situ to assess the change of safety factor. The laboratory investigation focused on river and embankment characteristics including the analysis of the drying-wetting conditions. In-situ and laboratory investigations found an extreme condition which the infrastructures are subjected into, where the water level and flow velocity were $3 \mathrm{~m}$ and $0.04-0.27 \mathrm{~m} / \mathrm{s}$ during dry season; and $10 \mathrm{~m}$ and $0.46-0.84 \mathrm{~m} / \mathrm{s}$ during rainy season. Furthermore, from the analysis, it can be concluded that certain areas in the river do not meet the minimum requirements for bridge foundation and embankment stability.
\end{abstract}

Keyword : infrastructure management, Bengawan Solo River, embankment, infrastructures, fluctuation, safety factor.

\section{INTRODUCTION}

Bengawan Solo River, the longest river on Java Island, Indonesia, has approximately $600 \mathrm{~km}$ in length and $20,000 \mathrm{~km}^{2}$ of catchment area. Embankments along the river have history of overtopping and failure throughout the year both during dry and wet seasons. The river embankment is built to secure the river are from flood and inundation (Maulana et al, 2019). Embankment failures can compromise the safety of people living in highly dense areas (810 people $/ \mathrm{km}^{2}$ ) behind the embankments and have been the main concern of the government.

Infrastructure is constructed to fulfil a function for the population in an area (Suprayitno \& Soemitro, 2018). Nearby infrastructures in Bengawan Solo river are built to secure the 
living inhabitants along the river. Improper land-use change, deforestation and local and mining along the river channel greatly increase surface runoff, flow, unbalanced of sedimentation, aggradations and degradation in the river. These combining effects resulted in unpredictable change in river morphology, potentially leading to flooding and infrastructure instability problems.

Measure of infrastructure stability is determined by safety factor which compares resistance and load. Commonly, this factor is almost always produced in an analysis of one extreme condition, which assumes that stability is static. However, this has failed to consider the variability of natural factors and importantly, the escalating threat of extreme environmental condition, induced by global climate change. This assumption should, therefore, be revisited for developing a more resilient design and maintenance regime. To demonstrate the changing infrastructure stability, an assessment of safety factor of river embankment and bridge foundation as nearby infrastructures along Bengawan Solo River's channel and estuary is presented. In 2007 until 2009, Bengawan Solo experienced heavy rainfall that inducing overtopped river embankment and innundated residential area due to flooding (Satrya et al, 2017). Since 2009, the water level has just at the top level of river embankment. For instance, stability of embankment and infrastructure is often influenced by drying-wetting condition during water level fluctuation. Piping phenomenon, as one of the cause of river embankment failure, is induced by the water-level difference between the inner and the outer part of the river embankment, and failure happens when the resisting moment becomes lower than the driving moment (Bischiniotis et al, 2016). In detail, piping induced by the rapid draw down phenomenon and high water level during rainy season affects the worst piping effect. Previous method only analyze the infrastructures on the constant water level which has no dynamic change consideration.

Lessons from past flooding and infrastructure failures in Indonesia suggest the need to investigate the characteristics of soil along the river channel to assess the stability of embankments and bridge foundation. Contribution of this research is to provide better understanding of safety factor analysis in assessing the assets infrastructure.

\section{OBSERVATION SITE}

Bengawan Solo River is located across Central and East Java provinces (Figure 1). It flows on alluvial soil and its embankment is usually made in-situ and predominantly soft silty soil taken from the river bed. Weakness of this soil type is that the strength could decrease rapidly due to the water infiltration mechanism. Therefore, considerable settlement, erosion and river water overtopping often lead to failure in the rainy seasons. Moreover, in the dry season, embankment fissuring leads to internal seepage and reduced resistance to shallow soil slippage.

The impact of embankment and infrastructure failure could be devastating. The extreme floods in the end of December 2007 and early January 2008 resulting in deaths of over 100 people and evacuation of around 200,000 people from their houses. Total economic loss including infrastructure (river embankment and infrastructure failures) is estimated at 2000 billion Indonesian rupiahs, or approximately US\$130,000 (Hidayat et al, 2008).

\section{METHODOLOGY}

\section{In - Situ Investigation}

In-situ investigations consisted of field investigation, field survey and laboratory investigation and were undertaken during dry and rainy seasons. The field investigation observes the hydrological and geotechnical aspects from in-situ condition. Field survey is to investigate the physical appearance and the physical design of the bridges along the 
observation site. The laboratory investigation concerns on the characteristic testing of soil obtained from field investigation. The results allow a thorough assessment of stability of embankment and bridge foundations.

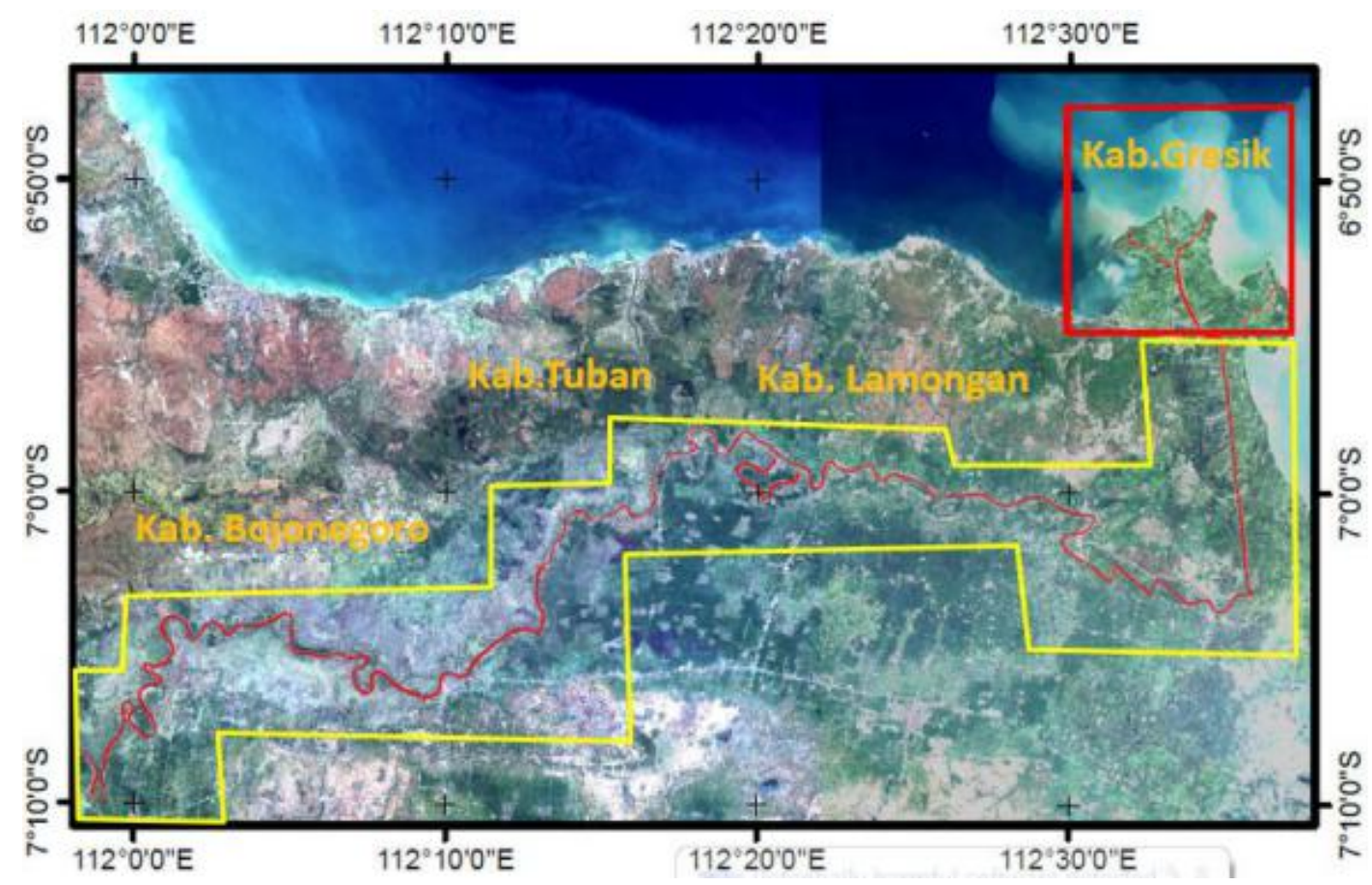

Figure 1. Research Study Location

- Field investigation

The river investigations consist of river morphology, water fluctuations and flow velocity. The soil investigation focuses on the soil resistivity along the river and also the behaviour of embankment soil.

- Field survey

Four bridges which has long span (more than $40 \mathrm{~m}$ ), along the downstream channel until estuary area, were investigated, including Karang Geneng, Karang Binangun, Laren and Sembayat. All were surveyed on its physical appearance and physical foundation design. Due to data availability, soil characteristics along these bridges are obtained from secondary data.

- Laboratory investigation

The embankment soil obtained from field investigation was tested in the laboratory under drying and wetting condition. From this condition, change of the physical and mechanical characteristics could be observed.

\section{RESULTS AND DISCUSSION}

\section{Hydrological Aspect}

- River morphology

Erosion and deposition of sediment are two main phenomena that occurred in river stream. The sediment erosion can be found at the outer river bend, while the deposition is generally occurred at the inner part of river bend. The investigation is resulted that the outer part of river curve has 1.5 up to 2.5 times deeper than inner curve as shown in the 
Figure 2. It proves that the erosion occurred at the outer side, while the sedimentation is happening at the inner side of river bend.

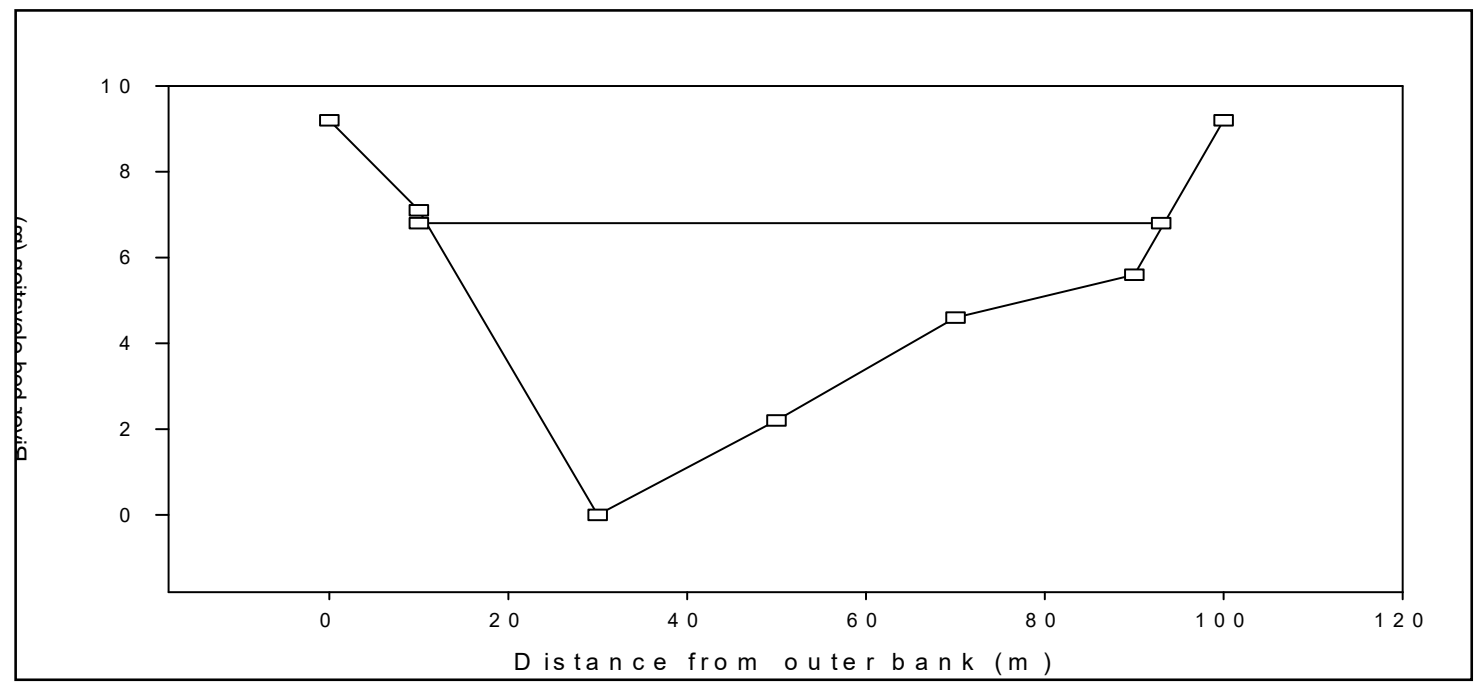

Figure 2. River Profile at the Curve Section

- Water fluctuations

Regarding the field investigation result, the lowest average water level is $3 \mathrm{~m}$ during dry season, while the maximum water level is averaged at $10 \mathrm{~m}$ for the period of rainy season (Figure 3). Further analysis shows that the water level fluctuations affect the flow conditions. In advances, the flow discharge can be calculated based on the flow velocity and water depth.

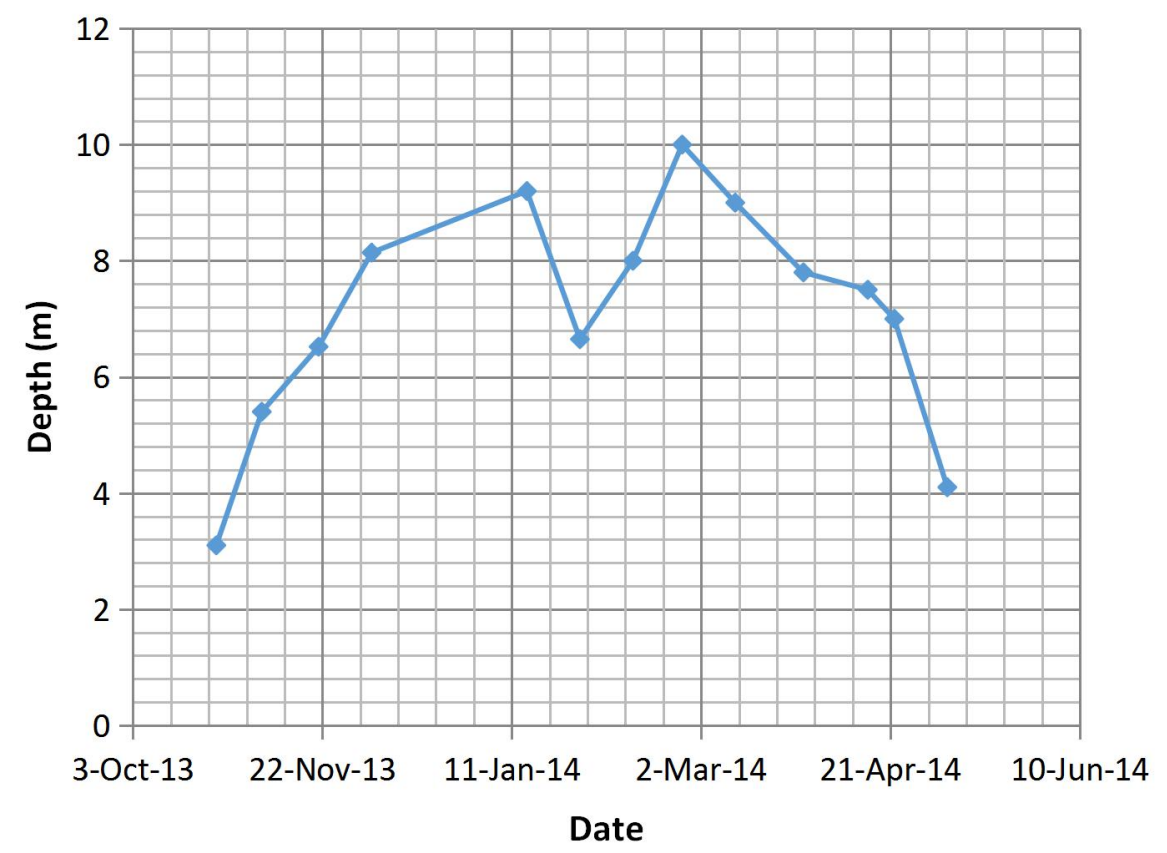

Figure 3. Water level fluctuations

- Flow velocity

In normal condition, the low flow velocity is indicating the dry season state, while high flow velocity represents the rainy season circumstance. The measurement shows that during dry season the flow velocity is ranged between 0.04 and $0.27 \mathrm{~m} / \mathrm{s}$. In the other 
hand, the rainy season shows great difference in which the flow velocity is averaged between 0.46 and $0.84 \mathrm{~m} / \mathrm{s}$ (Figure 4). Both of dry and rainy periods, the maximum velocity is occurred at around the outer river bend. It triggers the erosion and failure as the consequences.

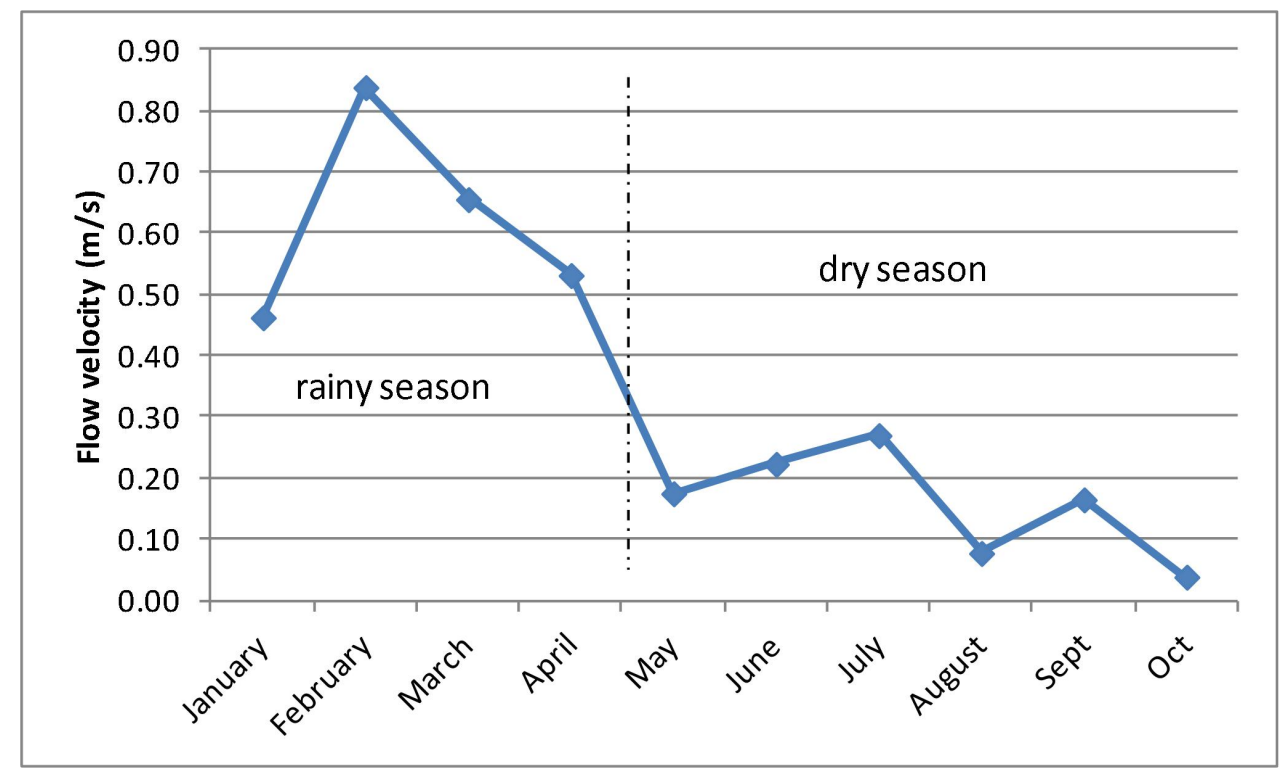

Figure 4. Average Flow Velocity Fluctuation During Dry and Rainy Seasons

\section{Geotechnical Aspects}

- Soil resistivity

Resistivity test was conducted in the river embankment body to better understand about soil statigraphy layered in the embankment. It shows that the surface soil $(0-5 \mathrm{~m})$ is dominated by clayey silt soil, otherwise the bottom soil layer $(5 \mathrm{~m}-60 \mathrm{~m})$ is dominated by saturated silty clay.

- Drying-wetting condition

Drying-wetting test was conducted at laboratory to identify how the change of water content influences soil characteristics. The test shows that the physical and mechanical soil characteristics are mostly influenced by the drying-wetting cycles. The high difference of undrained shear strength value, $\mathrm{cu}(125 \mathrm{kPa})$ during drying wetting cycles indicate that the characteristics is affected by the cycles as well. It implies that the undrained shear strength value decreases as the cycle increases.

- Infrastructures and Embankment

The stability of four bridges which identified in Table 1 was assessed in term of scouring, erosion caused by sedimentation and river flow velocity.

Table 1. Bridges Along the Research Study Location

\begin{tabular}{lccccc}
\hline No. & Area & $\begin{array}{c}\text { Total } \\
\text { span } \\
(\mathrm{m})\end{array}$ & $\begin{array}{c}\text { Number } \\
\text { of } \\
\text { pillars }\end{array}$ & $\begin{array}{c}\text { Main } \\
\text { span } \\
(\mathrm{m})\end{array}$ & Width (m) \\
\hline 1 & Karang Binangun & 150 & 2 & 60 & 10 \\
\hline 2 & Karang Geneng & 130 & 2 & 60 & 7.5 \\
\hline 3 & Laren & 130 & 2 & 60 & 8.0 \\
\hline 4 & Sembayat & 130 & 2 & 60 & 10 \\
\hline
\end{tabular}


Soil boring log result from secondary data near the bridge area is used for evaluating the embankment stability. There are 4 (four) layers consists of clay layer as surface layer; sandy clay and silty sand as middle layer; and silty clay as bottom layer. Summary of soil properties at each layer is shown in Table 2.

These soil layers would compose the soil below the river embankments, all of the observed areas are using these data. Observed embankment area is similar with the bridge foundation area, which consists of : Karang Binangun, Karang Geneng, Laren and Sembayat area.

Table 2. Summary of Soil Properties

\begin{tabular}{ccccccc}
\hline No. & $\begin{array}{c}\text { Depth (from } \\
\text { surface) }\end{array}$ & $\begin{array}{c}\text { N SPT } \\
\text { (blows/feet) }\end{array}$ & Soil Type & $\begin{array}{c}\text { Unit } \\
\text { weight } \\
\left(\mathbf{k N} / \mathbf{m}^{3}\right)\end{array}$ & $\begin{array}{c}\text { Cohesion } \\
(\mathbf{k P a})\end{array}$ & $\begin{array}{c}\text { Internal } \\
\text { angle } \\
\text { friction } \\
\left(\mathbf{\circ}^{\mathbf{}}\right.\end{array}$ \\
\hline $\mathbf{1}$ & $0.00-5.00 \mathrm{~m}$ & 8 & Clay & 16.44 & 18.3 & 4 \\
\hline $\mathbf{2}$ & $5.00-15.00 \mathrm{~m}$ & 10 & Sandy Clay & 16.89 & 21.7 & 5 \\
\hline $\mathbf{3}$ & $15.00-25.00 \mathrm{~m}$ & 26 & Silty Sand & 14.96 & 1 & 27 \\
\hline $\mathbf{4}$ & $25.00-60.00 \mathrm{~m}$ & 39 & Silty Clay & 20.00 & 50 & 37.8 \\
\hline
\end{tabular}

- $\quad$ Bridge Foundation Stability

In term of axial load, all of the bridge area is safe except Karang Geneng area where if the wind load and water level increasing are applied in the same time, the bridge foundation would be collapsed. In term of lateral load, all of the bridge area has the same collapsing problem in combination 10 where the water level increases until $10 \mathrm{~m}$ and the wind load also reach the maximum value.

However, in Sembayat Bridge, all of the load combination is safe because the pile capacity value is more than the given load. It might be due to the simplification of bridge foundation shape, hence it has very minimum area to be loaded by wind and water. The foundation at Sembayat bridge only consists of pile foundation and pile cap. The foundation shapes at Sembayat Bridge are recently proven to minimize the loads triggered by the wind and water.

- Embankment Stability

The summary of safety factors for all observed area is presented in Table 3 below.

Table 3. Summary of Safety Factor

\begin{tabular}{|c|c|c|c|c|}
\hline Safety Factor & $\begin{array}{c}\text { Karang } \\
\text { Binangun }\end{array}$ & $\begin{array}{c}\text { Karang } \\
\text { Geneng }\end{array}$ & Laren & Sembayat \\
\hline $\boldsymbol{\Delta}_{\text {water } \mathbf{0 ~} \mathbf{~ m}}$ & 0.862 & 3.085 & 2.076 & 1.514 \\
\hline $\boldsymbol{\Delta}_{\text {water }} \mathbf{2 . 5} \mathbf{~ m}$ & 0.912 & 5.822 & 2.495 & 1.69 \\
\hline $\boldsymbol{\Delta}_{\text {water }} \mathbf{5 . 0} \mathbf{~ m}$ & 1.006 & 7.175 & 4.602 & 2.08 \\
\hline $\boldsymbol{\Delta}_{\text {water }} \mathbf{7 . 5} \mathbf{~ m}$ & 1.149 & 7.175 & 4.602 & 2.795 \\
\hline $\boldsymbol{\Delta}_{\text {water }} \mathbf{1 0} \mathbf{~ m}$ & 1.328 & 7.175 & 4.602 & 3.27 \\
\hline
\end{tabular}

The safety factors presented in Table 3 show that due to the water level fluctuation, all of observed area is secure from river embankment failure except Karang Binangun area. The Karang Binangun area has lower safety factor which less than 1.5, it might be due to the geometry shape that prone to be collapsed. The stability also becomes worst 
due to the water level fluctuation. Unsaturated soil condition has considerable impact on river embankment stability (Fan \& Hsiao, 2010).

\section{CONCLUSION}

This paper assesses the change of safety factor of assets infrastructures as well as river embankment along the Bengawan Solo river. This was accomplished by conducting an in-situ investigation and laboratory tests. The major conclusions can be summarized as follows :

- The water level and flow velocity are $3 \mathrm{~m}$ and $0.04-0.27 \mathrm{~m} / \mathrm{s}$ during dry season; and 10 $\mathrm{m}$ and $0.46-0.84 \mathrm{~m} / \mathrm{s}$ during rainy season. It implies that in this river, the rainy season has greater difference comparing with dry season.

- Axial and lateral loads are the critical loads that define the safety condition of bridge foundation due to water level fluctuation.

- From axial load analysis, all of the bridge area is safe except Karang Geneng bridge that has collapsed possibility when the wind and water level fluctuation occurs in the same time.

- Regarding the lateral load analysis, all of the bridge area has the same collapsed problem when the water level increases until $10 \mathrm{~m}$ and wind load also reaches maximum value.

- From all of the bridge foundation analysis, Sembayat bridge is classified as the high safety bridge since safe condition has been notified for all of both axial and lateral load combinations.

- In term of river embankment stability issues, all of observed area except Karang Binangun is secured from water level fluctuation influence. The geometry shape and water level fluctuation induce embankment failure in Karang Binangun area.

- Suggestions are briefly described by the author with a clear language, has an object target and in the form of an appeal to conduct similar research that emphasizes the deepening of the object.

ACKNOWLEDGEMENT. This research is fully supported by Partnerships for Enhanced Engagement in Research (PEER Science Cycle 3), Directorate General of Higher Education Indonesia (DIKTI) and LPPM-ITS for the research scheme funds.

\section{REFERENCES}

Bischiniotis, K., Kanning, W., Jonkman, S.N., \& Kok, M. (2016). "Cost-optimal design of river dikes using probabilistic methods”. Journal of Flood Risk Management, pp. 1-13. DOI: $10.1111 /$ jfr3.12277.

Fan, Ch., \& Hsiao, Ch. (2010). "Effect of Slope Terrain on Distribution of Matric Suction in Unsaturated Slopes Subjected to Rainfall", Geotechnical Special Publication, Experimental and Applied Modeling of Unsaturated Soils, Copyright ASCE 2010, pp $128-136$.

Hidayat, F., Sungguh, H. M., \& Harianto. (2008). "Impact of Climate Change on Floods in Bengawan Solo and Brantas River Basins, Indonesia", 11th International River Symposium in Brisbane, Australia, 1 - 4 September 2008, published online at www.riversymposium.com.

Maulana, M.A., Suprayitno, H., \& Soemitro, R.A.A. (2019). "Preliminary Recognition of RiverInfrastructure “, Journal of Infrastructure \& Facility Asset Management, Vol. 1, Issue 1, March 2019.

Satrya, T.R., Soemitro, R.A.A., Mukunoki, T. \& Indato. (2017). "Change of Soil Properties in the Bengawan Solo River Embankment due to Drying-Wetting Cycles", Journal of 
(e)ISSN 2656-8896 (p)ISSN 2656-890X

Journal of Infrastructure and Facility Asset Management - Vol. 1, Issue. 2, September 2019

the Southeast Asian Geotechnical Society (SEAGS) and Association of Geotechnical Societies in Southeast Asia (AGSSEA) - Vol. 48 no.4, pp. 58-68, December 2017 (ISSN 0046-5828).

Suprayitno, H., \& Soemitro, R.A.A. (2018). "Preliminary Reflexion on Basic Principle of Infrastructure Asset Management “, Jurnal Manajemen Aset Infrastruktur \& Fasilitas Vol. 2, No. 1, Maret 2018. 